\title{
Quality Analysis of AITi5B1 Master Alloys
}

Jaroslava Svobodova ${ }^{1}$, Peter Hajdúch ${ }^{2}$

${ }^{1}$ Faculty of Mechanical Engineering, J. E. Purkyně University in Ústí nad Labem, Pasteurova 7, 40001 Ústí nad Labem. Czech Republic. E-mail: jaroslava.svobodova@ujep.cz

${ }^{2}$ Nemak Linz GmbH, Zeppelinstraße 24, 4030 Linz. Austria. E-mail: peter.hajduch@nemak.com

Grain refinement in commercial aluminium alloys can be achieved by addition of AITi5B1 master alloy, containing $\alpha$ aluminium matrix, $\mathrm{TiB}_{2}$ and $\mathrm{Al}_{3}$ Ti particles. These particles act as nucleation points for $\alpha$ Al matrix, resulting in a uniform fine, equiaxed as cast microstructure. Current grain-refinement practice involves the addition of master alloy (e.g. Al-Ti-B, Al-Ti-C) before casting introducing inoculants particles to the melt. The final size SDAS in aluminium cast alloys depends on the kinetics of both nucleation and growth of solid in the liquid. As per the classical nucleation theory, the critical activation energy $\left(\Delta G^{*}\right)$ to form stable nucleus and the critical radius ( $\left.r_{k r}\right)$ for the nucleus to grow into a crystal with long order atomic arrangement are inversely proportional to the undercooling. In practical instances, nucleation does not occur heterogeneously on solid substrates such as mould walls. Several works, mainly regarding primary foundry alloys, have been carried out on grain refinement revealing how the $\mathrm{TiB}_{2}$ particles present in AITi5B1 master alloy provide a germ for heterogeneous nucleation; however, these particles become efficient grain refiners only with excess Ti content. This condition can not only increase the nucleating potency of $\mathrm{TiB}_{2}$ particles, but also reduce the grain growth of primary $\alpha$ - Al crystals during solidification. At atomic scale the nucleating potency of $\mathrm{TiB}_{2}$ is dictated by the mismatch between the lattice of this particle and the nucleating phase. The performance of AITi5B1, well established to be the best grain refiner for cast aluminium alloys as AISi7Mg0.3 and AISi12Cu2. Producer of the master alloys as AITi5B1 guarantee the chemical composition but not size of particles that are very important for solidification process. This review focuses on the quality of five AITi5B1 master alloys.

Keywords: Aluminium casting alloys, Master alloys applied for refining of the structure, AlTi5B1 master alloy analysis.

\section{References}

[1] BIROL, V. (2012). Performance of AlTi5B1, AlTi3B3 and AlB3 Master Alloys in Refining Grain Structure of Aluminium Foundry Alloys. Material Science and Technology, Vol. 28, Issue 4, pp. 481-486.

[2] SCHUMACHER, P. et al (2013). New Studies of Nucleation Mechanisms in Aluminium Alloys: Implication for Grain Refinement Practice. Material Science and Technology, July, Vol. 14, Issue 5, pp. 394-404.

[3] BOLZONI, L. et al (2016). Engineering the Heterogeneous Nuclei in Al-Si Alloys for Solidification Control. Applied Materials Today, December, Vol. 5, pp. 225-259.

[4] SIGWORTH, C., K. et al (2014). Fundamentals of Solidification in Aluminium Castings. International Journal of Metal casting, January, Vol. 8, Issue 1, pp. 7-20.

[5] GUTIÉRREZ, V. et al (2014). Thermal Analysis of Grain Refinement and Modification of an A 356 Cast Alloy. Chemistry and Material Research, Vol. 6, No. 6, pp. 52 - 62.

[6] MANDUIT, A. et al (2015). Application Study of AlSi10Mg Alloy by Selective Melting: Physical and Mechanical Properties, Microstructure, Heat Treatment and Manufacturing of Aluminium Metallic Matrix Composite (MMC). Metall. Res. Technol., Vol. 112, Number 6, pp. $605-628$.

[7] NOVAKOVA, L., HOMOLA, P., KAFKA, V. (2012). Microstructure Analysis of Titanium Alloys after Deformation by means of Asymmetric Incremental Sheet Forming. Manufacturing Technology, Vol. 12, No. 13, pp. 201-206.

[8] CHAN, Y., J. (2012). Effect of Alloying Elements on High Temperature Mechanical Properties on Piston Alloy. Materials Transaction, Vol. 53, No. 1, pp. $234-239$.

[9] GALE, W., F., TOTEMEIER, T., C. (1992). Smithells Metals Reference Book. Elsevier Butterworth - Heinemann, $7^{\text {th }}$ Edition, Oxford, Great Britain.

[10] JI, S. et al (2013). Effect of Ti Addition on Mechanical Properties of High Pressure Die Cast Al-Mg-Si Alloys. Science Forum, Vol. 765, pp. 23 - 27.

[11] FARKOOSH, A., R. et al (2015). Dispersion Strengthening of a High Temperature Al - Si - Cu - Mg Alloy via Mo Addition. Materials Science and Engineering, December, pp. 181 - 189. 
[12] KNAISLOVÁ, A., NOVAK, P., NOVÁ, K. (2016). Using of Microscopy in Optimization of the Ti-Al-Si Alloys Preparation by Powder Metallurgy. Manufacturing Technology, Vol. 16, No. 5, pp. 946-949.

[13] LIAO, H., C. et al (2010). Eutectic Solidification in Near-eutectic Al - Si Casting Alloys. JMST, Vol. 12, pp. $1089-1097$.

[14] MCDOWELL, D., L. et al (2003). Microstructure Used Fatigue Modelling of Cast A356 - T6 Alloy. Engineering Fracture Mechanics, Vol. 70, 2003, pp. 49-80.

[15] KNOLL, O., A. (2015). Probabilistic Approach in Failure Modelling of Aluminium High Pressure Die-Castings. NTNO, Trondheim, Norway, PhD. Thesis.

[16] RANA, R., S. et al (2012). Reviews on the Influence of Alloying Elements on the Microstructure and Mechanical Properties of Aluminium Alloys and Aluminium Composites. International Journal of Scientific and Research Publications, June, Vol. 2, Issue 6, pp. 1 -6.

Copyright (C) 2017. Published by Manufacturing Technology. All rights reserved. 